\title{
Perencanaan Strategis Sistem Informasi dan Teknologi Informasi di Dinas Pendapatan, Pengelolaan Keuangan dan Aset Kabupaten Kampar (Model Strategis Ward and Peppard)
}

\author{
Abdul Aziz ${ }^{1}$, Teddie Darmizal ${ }^{2}$ \\ ${ }^{1,2}$ Teknik Informatika, UIN Sultan Syarif Kasim Riau \\ Jl. H.R. Soebrantas no. 155 KM. 18 Simpang Baru, Pekanbaru 28293 \\ kangajiez21@gmail.com ${ }^{1}$, teddie.darmizal@uin-suska.ac.id ${ }^{2}$
}

\begin{abstract}
Abstrak -Pengelolaan Keuangan dan Aset Kabupaten Kampar sebagai sistem perangkat daerah yang berfungsi dalam Pendapatan, Pengelolaan Keuangan dan Aset Daerah dalam menjalankan tugas, pokok dan fungsinya tidak terlepas dari kinerja bidang-bidang yang memiliki peran dan fungsinya masing-masing yang telah menjadi sebuah mekanisme kerja yang dinamis. Permasalahan yang terjadi di DPPKA Kampar. Pertama, Belum adanya portofolio aplikasi SI untuk mendukung bisnis. Kedua, infrastruktur yang belum memadai. Ketiga, tidak memiliki sub bagian yang mengelola SI/TI. Keempat, sulit menentukan investasi TI yang tepat. Maka diperlukan membuat suatu perencanaan strategis SI dan TI untuk DPPKA Kampar. Perencanaan strategis SI/TI ini dibuat dengan menggunakan framework ward and peppard dengan beberapa metode analisa yaitu analisa value chain, dengan memetakan apa saja aktivitas utama dan pedukng yang ada di DPPKA Kampar dan menganalisa permasalahan setiap aktivitas. Untuk melihat kekuatan, kelemahan, peluang dan ancaman maka digunakan analisa SWOT (Strenght, Weakness, Oppurtunity, Thread). Faktor-faktor yang menjadi keberhasilan dan bisa menyelesaikan masalah dan kebutuhan maka digunakan analisa CSFs (Critical Success Factors). Analisa McFarlan Strategic Grid digunakan untuk memetakan aplikasi yang ada di DPPKA Kampar berdasarkan kategori yaitu support, Key Operational, Strategic dan High Potential. Hasil yang dicapai melalui metode analisa tersebut adalah rekomendasi berupa 20 sistem informasi, 10 teknologi informasi dan 4 manajemen SI dan TI. Sistem informasi dan teknologi informasi tersebut dibuat dalam bentuk roadmap yang akan diterapkan selama 5 tahun kedepan oleh DPPKA Kampar..
\end{abstract}

Kata Kunci - Perencanaan strategis sistem informasi dan teknologi informasi, DPPKA, Ward and Peppard.

\section{PENDAHULUAN}

Dinas Pendapatan, Pengelolaan Keuangan dan Aset (DPPKA) Kabupaten Kampar sebagai salah satu sistem perangkat daerah yang berfungsi dalam Pendapatan, Pengelolaan Keuangan dan Aset Daerah dalam menjalankan tugas, pokok dan fungsinya tidak terlepas dari kinerja bidang-bidang yang memiliki peran dan fungsinya masing-masing yang telah menjadi sebuah mekanisme kerja yang dinamis.

Dinas Pendapatan, Pengelolaan Keuangan dan Aset (DPPKA) Kabupaten Kampar mengembangkan sistem informasi dan teknologi informasi tanpa melakukan perencanaan strategis sistem informasi dan teknologi informasi. Dinas tersebut mengembangkan sistem informasi dan teknologi informasi hanya dengan bantuan staff internal maupun vendor (eksternal) secara langsung. Akibat dari hal tersebut adalah terbentuknya sistem informasi dan teknologi informasi yang bersifat "Tambal Sulam".

Sebagai contoh, jika dinas tersebut menganggarkan dana untuk pembelian aplikasi di bidang pelayanan pajak daerah, jika aplikasi tersebut tidak direncanakan modul yang ada di dalamnya, maka suatu saat dinas tersebut akan mengalami kesulitan apabila modul yang ada pada aplikasi yang telah dibeli tersebut tidak sesuai dengan tujuan dan arahan jangka panjang dari dinas tersebut. Akibatnya dinas tersebut akan mengeluarkan dana lagi untuk membeli aplikasi baru untuk mengatasi kekurangan pada aplikasi sebelumnya. Untuk itu diperlukannya sebuah portofolio aplikasi SI sebagai acuan aplikasi apa saja yang sudah ada di dinas tersebut. Sama halnya dengan teknologi informasi, perangkat TI juga harus seimbang dengan aplikasi SI yang ada sehingga dalam menjalankan aplikasi SI tidak adanya mengalami kendala dalam menjalankan proses data.

Dinas Pendapatan, Pengelolaan Keuangan 
dan Aset (DPPKA) Kabupaten Kampar masih terkendala dalam pelayanan pajak karena belum menggunakan sistem informasi untuk mempercepat dan mempermudah dalam pelayanan pajak terutama pada Bidang Pendapatan Asli Daerah (PAD) yang masih menggunakan kertas atau form untuk melakukan proses bisnisnya. Dan juga tingkat kepatuhan masyarakat atau wajib pajak dalam melaksanakan kewajibannya membayar pajak juga rendah karena kurang mendapatkan informasi tentang pentingnya membayar pajak daerah.

Di Dinas Pendapatan, Pengelolaan Keuangan dan Aset Daerah Kabupaten Kampar tidak memiliki bagian pendukung IT pada struktur organisasinya sehingga ketika terjadi kesalahan pada sistem informasi terutama pada Bidang Pajak Bumi dan Bangunan (PBB) harus mengubungi perusahaan yang membuat sistem informasi tersebut dan dilakukan perbaikan dari jarak jauh sehingga dapat memperlambat proses bisnis pada bidang tersebut.

Pada penelitian ini diberikan batasan masalah yaitu: (1) Roadmap yang dibuat dan dikembangkan direncanakan untuk 5 (lima) tahun kedepan. (2) Perencanaan strategis SI/TI dibuat dan dikembangkan dari kondisi SI/TI pada saat ini agar dapat sesuai dengan arah dan perkembangan organisasi. (3) Metode analisis yang digunakan adalah SWOT, Value Chain, CSF,dan McFarlan Strategic Grid.

Tujuan yang ingin dicapai adalah memberikan gambaran dukungan apa yang bisa diberikan SI/TI kepada tingkat manajerial di lingkungan Dinas Pendapatan, Pengelolaan Keuangan dan Aset (DPPKA) Kabupaten Kampar dan menganalisa faktor-faktor yang menjadi permasalahan saat ini di lingkungan Dinas Pendapatan, Pengelolaan Keuangan dan Aset (DPPKA) Kabupaten Kampar.

\section{LANDASAN TEORI}

\section{A. Analisa Perencanaan Strategis SI/TI}

Teknik-teknik analisis yang digunakan dalam membuat perencanaan strategis sistem informasi dan teknologi informasi menggunakan framework Ward and Peppard adalah sebagai berikut:

\section{Analisis SWOT}

Analisa SWOT adalah metode perencanaan strategis yang digunakan untuk mengevaluasi kekuatan (strengths), kelemahan (weaknesses), peluang (opportunities), dan ancaman (threats) dalam suatu proyek atau suatu spekulasi bisnis.

Tabel 1. Matrik SWOT

\begin{tabular}{|c|c|c|}
\hline SWOT & Kekuatan (S) & Kelemahan (W) \\
\hline $\begin{array}{l}\text { Peluang } \\
\text { (O) }\end{array}$ & $\begin{array}{l}\text { Strategi untuk } \\
\text { memanfaatkan } \\
\text { peluang untuk } \\
\text { mendayaguna } \\
\text { kan kekuatan } \\
(\text { Strategi S-O) }\end{array}$ & $\begin{array}{l}\text { Strategi untuk } \\
\text { memanfaatkan } \\
\text { peluang untuk } \\
\text { mengatasi } \\
\text { kelemahan } \\
(\text { Strategi W-O) }\end{array}$ \\
\hline $\begin{array}{l}\text { Ancaman } \\
\text { (T) }\end{array}$ & $\begin{array}{c}\text { Strategi untuk } \\
\text { mengatasi } \\
\text { ancaman } \\
\text { dengan jalan } \\
\text { mendayaguna } \\
\text { kan kekuatan } \\
\text { (Strategi S-T) }\end{array}$ & $\begin{array}{c}\text { Strategi untuk } \\
\text { menghindari } \\
\text { ancaman } \\
\text { sekaligus } \\
\text { melindungi } \\
\text { kelemahan } \\
\text { (Strategi W-T) }\end{array}$ \\
\hline
\end{tabular}

\section{Analisis Value Chain}

Menurut O'brien (2005, p68), Konsep Rantai Nilai yang dikembangkan oleh Michael Porter memandang suatu perusahaan sebagai rangkaian dari aktivitas dasar ("rantai") yang menambah nilai kepada produk dan jasanya untuk mendukung pencapaian suatu keuntungan. Di dalam konsep rantai nilai, beberapa aktivitas bisnis adalah merupakan aktivitas utama sedangkan aktivitas yang lain merupakan pendukung. Untuk masing-masing aktivitas, peran dari Sistem Informasi Strategis (SIS) akan memberikan kontribusi yang berarti dalam mendukung kontribusi setiap aktivitas tersebut kepada rantai nilai yang ada.

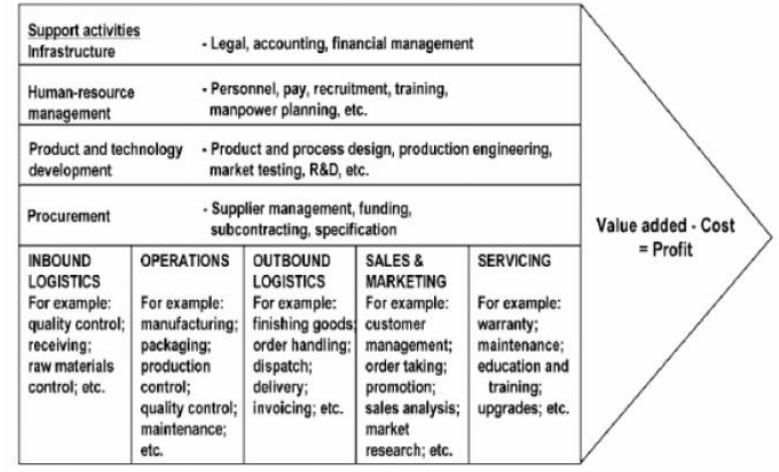

Gambar 1. Value Chain

\section{Analisis Critical Success Factors (CSFs) \\ Menurut Ward dan Peppard (2002), analisis \\ critical success factor (CSF) merupakan area}


terbatas dalam suatu bisnis yang apabila terpenuhi maka akan menjamin kesuksesan kinerja kompetitif bagi perusahaan.

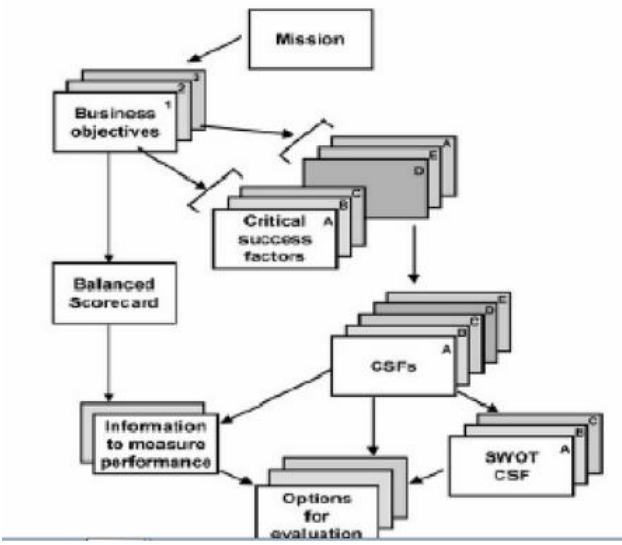

Gambar 2. Critical Success Factors (CSFs)

4. Analisis McFarlan Strategic Grid

Portofolio Aplikasi Mcfarlan digunakan untuk menilai kontribusi SI/TI secara keseluruhan dan efeknya terhadap kesuksesan bisnis. Menurut Ward dan Peppard (2002) portofolio aplikasi adalah cara untuk membawa bersama.

Tabel 2. McFarlan Grid Strategic

\begin{tabular}{|c|c|}
\hline Strategic & High Potential \\
\hline $\begin{array}{c}\text { Application that are } \\
\text { critical to sustaining } \\
\text { future business } \\
\text { strategy }\end{array}$ & $\begin{array}{c}\text { Applications that may } \\
\text { be important in } \\
\text { achieving future } \\
\text { success }\end{array}$ \\
\hline $\begin{array}{c}\text { Applications on } \\
\text { which the } \\
\text { organization } \\
\text { currently depend } \\
\text { for success }\end{array}$ & $\begin{array}{c}\text { Applications that are } \\
\text { valuable but not critical } \\
\text { to success }\end{array}$ \\
\hline Key Operational & Support \\
\hline
\end{tabular}

Dalam portofolio aplikasi sebuah aplikasi dapat dikategorikan sebagai strategic, high potential, key operational, atau support tergantung dari peranannya dalam mendukung strategi bisnis perusahaan, baik pada saat ini maupun di masa mendatang.

\section{METODOLOGI PENELITIAN}

Metodologi yang digunakan dalam penelitian ini dapat dilihat pada gambar 6 dibawah ini:

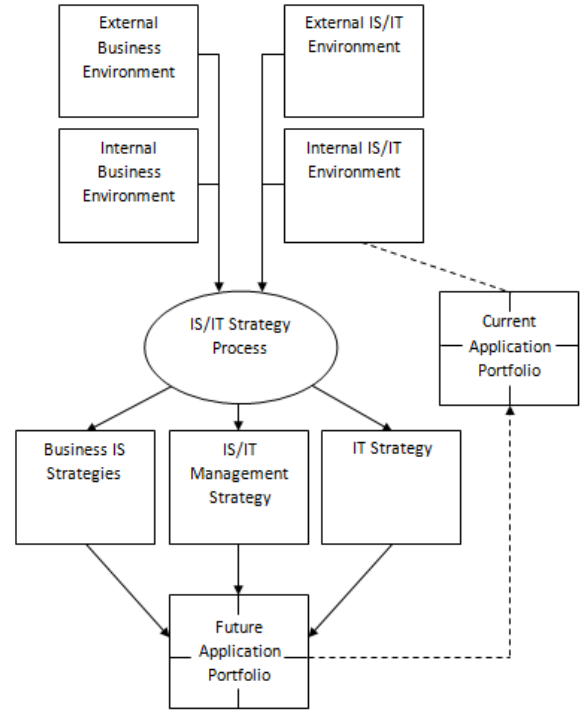

Gambar 3. Model Strategis Ward and Peppard

Model strategi SI/ TI ini memerlukan analisis terhadap empat masukan (input) sebagai berikut:

a. Lingkungan bisnis internal, mencakup strategi bisnis yang sedang dijalankan saat ini. Teknik analisis yang digunakan untuk lingkungan bisnis internal adalah SWOT, Value Chain, dan Critical Succses Factors

b. Lingkungan bisnis eksternal, mencakup kondisi politik, ekonomi, sosial, teknologi industri, dan iklim persaingan.

c. Lingkungan SI/ TI internal, mencakup teknologi informasi yang dipakai saat ini.

d. Lingkungan SI/ TI eksternal, mencakup tren teknologi

Output yang dihasilkan dari perencanaan strategik sistem informasi ini menghasilkan tiga keluaran, sebagai berikut:

a. Strategi bisnis sistem informasi, bagaimana masing-masing unit dalam perusahaan dapat

b. mengimplementasikan/ memanfaatkan SI/ TI untuk mencapai tujuan bisnis orgnisasi.

c. Strategi teknologi informasi, bagaimana kebijakan dan strategi untuk mengelola teknologi dan sumber daya manusianya.

d. Strategi manajemen, mencakup elemen-elemen umum yang diterapkan melalui organisasi, untuk memastikan konsistensi penerapan kebijakan SI/ TI yang dibutuhkan.

Hasil akhir dari perencanaan strategis SI/ TI adalah sebuah portofolio aplikasi yang akan datang. 


\section{ANALISA SI/TI}

\section{A. Analisa Lingkungan Bisnis Internal Analisa Value Chain}

Analisa value chain adalah pemetaan aktivitas utama dan pendukung yang ada di DPPKA Kampar, dari aktivitas tersebut maka kita dapat menemukan permasalahan-permasalahan dari aktivitas utama dan aktivitas pendukung.

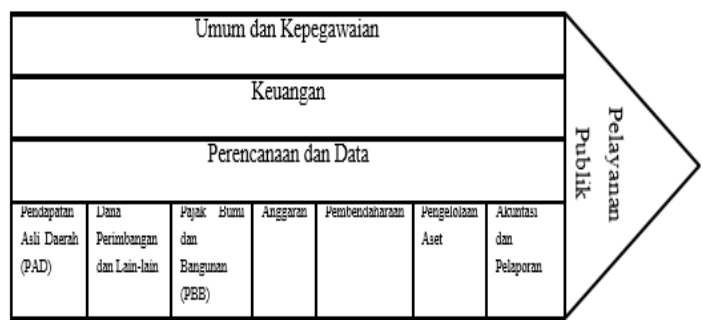

Gambar 4. Value Chain DPPKA Kampar

\section{Analisa SWOT}

Analisa SWOT dilakukan untuk mengidentifikasi faktor-faktor strategis suatu organisasi yang terdiri dari Kekuatan (Strenghts),

Kelemahan (Weaknesses), Peluang (Opportunities) dan Ancaman (Threats) yang ada di DPPKA Kampar. Dengan mengetahui kekuatan dan peluang DPPKA maka akan dapat meningkatkan keunggulan startegis bagi DPPKA Kampar.

Tabel 3. Analisa SWOT DPPKA Kampar

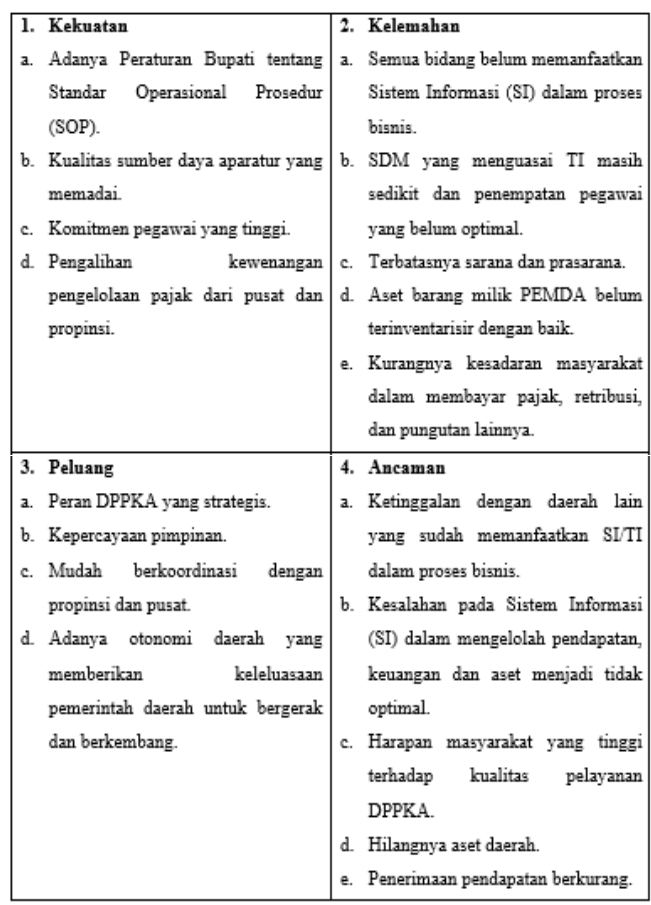

Analisa Critical Success Factors (CSFs)

Analisa Critical Success Factors adalah menganalisa faktor keberhasilan dari permasalahan-permasalahan yang ada pada analisa value chain dan kebutuhannya. Dari analisa CSF maka didapatkan faktor keberhasilan dari permasalahan dan kebutuhan yang dijabarkan di setiap bidang dan subbidang.

Tabel 4. Analisa CSFs

\begin{tabular}{|c|c|c|}
\hline \multicolumn{3}{|c|}{ Pendapatan Asli Daerah } \\
\hline Permasalahan & Kebutuhan & CSFs \\
\hline $\begin{array}{l}\text { Rendahnya } \\
\text { tingkat } \\
\text { kepatuhan } \\
\text { Wajib Pajak } \\
\text { (WP) terutama } \\
\text { pajak hotel dan } \\
\text { restoran tahun } \\
2014 \text { dan } \\
2015 \text {. }\end{array}$ & $\begin{array}{l}\text { Peningkatan } \\
\text { penerimaan } \\
\text { pajak daerah }\end{array}$ & $\begin{array}{l}\text { Melakukan } \\
\text { sosialisasi } \\
\text { secara rutin } \\
\text { baik dalam } \\
\text { bentuk } \\
\text { tulisan } \\
\text { maupun } \\
\text { lisan }\end{array}$ \\
\hline \multicolumn{3}{|c|}{$\begin{array}{c}\text { Dana Perimbangan dan Lain-lain } \\
\text { Pendapatan }\end{array}$} \\
\hline Permasalahan & Kebutuhan & CSFs \\
\hline $\begin{array}{l}\text { Dana dari } \\
\text { pusat yang di } \\
\text { transfer ke } \\
\text { daerah dalam } \\
\text { bentuk } \\
\text { pendapatan di } \\
\text { APBD sering } \\
\text { terjadi } \\
\text { keterlambatan. }\end{array}$ & $\begin{array}{l}\text { Hubungan } \\
\text { kerjasama } \\
\text { dengan pusat } \\
\text { dan propinsi }\end{array}$ & $\begin{array}{l}\text { Melakukan } \\
\text { komunikasi } \\
\text { dengan pusat } \\
\text { dan proponsi } \\
\text { untuk } \\
\text { mengetahui } \\
\text { sebab } \\
\text { keterlambata } \\
\text { n transfer } \\
\text { dana } \\
\text { perimbangan } \\
\text { ke daerah. }\end{array}$ \\
\hline \multicolumn{3}{|c|}{ Pajak Bumi dan Bangunan } \\
\hline Permasalahan & Kebutuhan & CSFs \\
\hline $\begin{array}{l}\text { Adanya Surat } \\
\text { Pemberitahuan } \\
\text { Pajak } \\
\text { Terhutang } \\
\text { (SP2T) yang } \\
\text { ganda. }\end{array}$ & $\begin{array}{l}\text { Data dan } \\
\text { pemetaan } \\
\text { lokasi pajak } \\
\text { bumi dan } \\
\text { bangunan } \\
\text { yang lengkap }\end{array}$ & $\begin{array}{l}\text { Melakukan } \\
\text { pendataan } \\
\text { kembali } \\
\text { terhadap } \\
\text { objek pajak } \\
\text { yang ada di } \\
\text { Kabupaten } \\
\text { Kampar }\end{array}$ \\
\hline \multicolumn{3}{|c|}{ Anggaran } \\
\hline Permasalahan & Kebutuhan & CSFs \\
\hline $\begin{array}{l}\text { SDM yang ahli } \\
\text { dibidang IT } \\
\text { masih belum } \\
\text { memadai }\end{array}$ & $\begin{array}{l}\text { SDM yang } \\
\text { lulusan IT dan } \\
\text { menguasai } \\
\text { dalam bidang } \\
\text { IT }\end{array}$ & $\begin{array}{l}\text { Melakukan } \\
\text { perekrutan } \\
\text { pegawai } \\
\text { yang lulusan } \\
\text { IT dan } \\
\text { menguasai } \\
\text { dalam } \\
\text { bidang IT }\end{array}$ \\
\hline
\end{tabular}




\begin{tabular}{|c|c|c|}
\hline \multicolumn{3}{|c|}{ Pembendaharaan } \\
\hline Permasalahan & Kebutuhan & CSFs \\
\hline $\begin{array}{l}\text { Sering } \\
\text { terlambatnya } \\
\text { pihak SKPD } \\
\text { yang menyetor } \\
\text { ke rekening } \\
\text { KASUMDA }\end{array}$ & $\begin{array}{l}\text { Komunikasi } \\
\text { yang baik } \\
\text { dengan SKPD } \\
\text { terkait }\end{array}$ & $\begin{array}{l}\text { Melakukan } \\
\text { pemberitahu } \\
\text { an kepada } \\
\text { SKPD } \\
\text { terkait } \\
\text { tentang } \\
\text { keterlambata } \\
\text { n menyetor } \\
\text { ke rekening } \\
\text { KASUMDA }\end{array}$ \\
\hline \multicolumn{3}{|c|}{ Pengelolaan Aset } \\
\hline Permasalahan & Kebutuhan & CSFs \\
\hline $\begin{array}{l}\text { Belum adanya } \\
\text { sistem } \\
\text { informasi } \\
\text { untuk } \\
\text { mengelola } \\
\text { asset daerah. }\end{array}$ & $\begin{array}{l}\text { Sistem } \\
\text { infrormasi } \\
\text { untuk } \\
\text { mengelola } \\
\text { asset } \\
\text { Kabupaten } \\
\text { Kampar }\end{array}$ & $\begin{array}{l}\text { Membuat } \\
\text { sebuah } \\
\text { sistem } \\
\text { informasi } \\
\text { untuk } \\
\text { mengeola } \\
\text { asset } \\
\text { Kabupaten } \\
\text { Kampar }\end{array}$ \\
\hline \multicolumn{3}{|c|}{ Akuntansi dan Pelaporan } \\
\hline Permasalahan & Kebutuhan & CSFs \\
\hline $\begin{array}{l}\text { Permendagri } \\
\text { No } 64 \text { tahun } \\
2013 \text { belum } \\
\text { optimal karena } \\
\text { kebijakannya } \\
\text { belum } \\
\text { diterapkan } \\
100 \% \text {. }\end{array}$ & $\begin{array}{l}\text { Pemahaman } \\
\text { tentang } \\
\text { kebijakan } \\
\text { permendagri } \\
\text { No } 64 \text { tahun } \\
2013\end{array}$ & $\begin{array}{l}\text { Penerapan } \\
\text { dan } \\
\text { melaksanaka } \\
\text { n kebijakan } \\
\text { permendagri } \\
\text { No } 64 \text { tahu } \\
2013 \text { secara } \\
\text { keseluruhan }\end{array}$ \\
\hline \multicolumn{3}{|c|}{ Umum dan Kepegawaian } \\
\hline Permasalahan & Kebutuhan & CSFs \\
\hline $\begin{array}{l}\text { Data pegawai } \\
\text { belum } \\
\text { terkelola } \\
\text { dengan baik } \\
\text { pada SUBAG } \\
\text { UMUM. }\end{array}$ & $\begin{array}{l}\text { Pengelolaan } \\
\text { data pegawai } \\
\text { terkomputeris } \\
\text { asi }\end{array}$ & $\begin{array}{l}\text { Melakukan } \\
\text { pendataan } \\
\text { pegawai dan } \\
\text { melakukan } \\
\text { komputerisa } \\
\text { si }\end{array}$ \\
\hline \multicolumn{3}{|c|}{ Keuangan } \\
\hline Permasalahan & Kebutuhan & CSFs \\
\hline $\begin{array}{l}\text { Penyusunan } \\
\text { laporan } \\
\text { keuangan } \\
\text { disesuaikan } \\
\text { dengan waktu } \\
\text { ditentukan }\end{array}$ & $\begin{array}{l}\text { Waktu untuk } \\
\text { penyusunan } \\
\text { laporan } \\
\text { keuangan }\end{array}$ & $\begin{array}{l}\text { Melakukan } \\
\text { penyusunan } \\
\text { laporan } \\
\text { keuangan } \\
\text { menggunaka } \\
\text { n sistem }\end{array}$ \\
\hline \multicolumn{3}{|c|}{ Perencanaan dan Data } \\
\hline Permasalahan & Kebutuhan & CSFs \\
\hline $\begin{array}{l}\text { Dalam hal } \\
\text { membuat } \\
\text { penyusunan } \\
\text { Rencana Kerja } \\
\text { Anggaran } \\
\text { (RKA) }\end{array}$ & $\begin{array}{l}\text { Waktu untuk } \\
\text { membuat } \\
\text { Rencana } \\
\text { Kerja } \\
\text { Anggaran } \\
\text { (RKA) }\end{array}$ & $\begin{array}{l}\text { Melakukan } \\
\text { penyusunan } \\
\text { Rencana } \\
\text { Kerja } \\
\text { Anggaran } \\
\text { (RKA) }\end{array}$ \\
\hline
\end{tabular}

\begin{tabular}{|l|l|l|}
\hline $\begin{array}{l}\text { membutuhkan } \\
\text { waktu yang }\end{array}$ & menggunaka \\
lama & n sistem \\
informasi
\end{tabular}

B. Analisa Lingkungan Bisnis Eksternal Gambaran Umum Lingkungan Bisnis Eksternal

Pemerintah Kabupaten Kampar merupakan pemerintah daerah yang berada di wilayah Propinsi Riau, Ibukota Kabupaten Kampar dipindahkan ke Bangkinang berdasarkan UU No. 12 tahun 1956. Kabupaten Kampar dengan luas lebih kurang 1.128.928 Ha merupakan daerah yang terletak antara $01^{\circ} 00^{\prime} 40^{\prime \prime}$ Lintang Utara sampai $00^{\circ} 28^{\prime} 30^{\prime \prime}$ Lintang Selatan dan 100²8'30" - 101¹4'30" Bujur Timur. Daerah ini terdiri dari 20 kecamatan dan 250 desa/kelurahan.

\section{Analisa SI/TI Internal}

Pemetaan SI Berdasarkan Analisa McFarlan Strategic Grid

\begin{tabular}{|c|c|}
\hline \begin{tabular}{ll}
\multicolumn{2}{l}{ Strategic } \\
$-\quad$ SIPKAD \\
$-\quad$ SISMIOP
\end{tabular} & High Potential \\
\hline $\begin{array}{l}\text { Key Operational } \\
-\quad \text { ВРНТВ }\end{array}$ & Support \\
\hline
\end{tabular}

\section{Analisa SI/TI Eksternal}

Agar dapat memperoleh gambaran tentang perkembangan SI/TI saat ini dilakukan analisa lingkungan SI/TI eksternal, yang mencakup trend teknologi perangkat keras, jaringan komputer dan sistem informasi. Tren teknlogi saat ini adalah teknologi 3G\&4G, WiFi, Cloud Computing, Mobile Application, dan Rich Internet Application (RIA).

\section{PERENCANAAN SI/TI}

\section{A. Perencanaan Strategi Bisnis SI}

Berdasarkan analisis lingkungan bisnis internal menggunakan analisis Value Chain dengan kebutuhan dan analisis Critical Sucsess Factor (CSF), maka di dapat kebutuhan SI atau Bisnis yang dipetakan dengan McFarlan Strategic Grid dapat dilihat pada Tabel 5 : 
Tabel 5. McFarlan Strategic Grid

\begin{tabular}{|c|c|}
\hline $\begin{array}{l}\text { Strategic } \\
\text { 1. SIPKAD } \\
\text { 2. SISMIOP } \\
\text { 3. SI Geografis } \\
\text { Berbasis Web } \\
\text { 4. SI Kinerja Pegawai } \\
\text { 5. SI Potensi Pajak } \\
\text { Daerah } \\
\text { 6. SI Manajemen Aset }\end{array}$ & $\begin{array}{l}\text { High Potential } \\
\text { Sistem informasi } \\
\text { forecasting } \\
\text { pendapatan dari lain- } \\
\text { lain pendapatan }\end{array}$ \\
\hline $\begin{array}{l}\text { Key Operational } \\
\text { 1. SIP Hotel } \\
\text { 2. SIP Restoran } \\
\text { 3. SIP Hiburan } \\
\text { 4. SIP Reklame } \\
\text { 5. SIP Air Tanah } \\
\text { 6. SIP Mineral Bukan } \\
\text { Logam dan Batuan } \\
\text { 7. SI Kepegawaian } \\
\text { 8. SI pemantauan } \\
\text { Pembayaran Pajak } \\
\text { 9. SI Pengolahan Dana } \\
\text { Perimbangan }\end{array}$ & $\begin{array}{ll}\text { Support } \\
\text { a. } & \begin{array}{l}\text { Sistem } \\
\text { pemberitahuan } \\
\text { menggunakan } \\
\text { sms gateway }\end{array} \\
\text { b. } & \begin{array}{l}\text { Pendaftaran dan } \\
\text { Pelaporan PAD }\end{array} \\
\text { c. } & \text { Registrasi } \\
& \text { Objek Pajak } \\
& \text { PBB } \\
\text { d. } & \text { Website } \\
& \text { Organisasi } \\
\text { e. } & \text { SI Validasi } \\
& \text { Dokumen } \\
\text { f. } & \text { Fitur pada } \\
& \text { website untuk } \\
& \text { pencarian SP2T }\end{array}$ \\
\hline
\end{tabular}

\section{B. Perencanaan Strategi TI}

Berikut ini adalah teknologi informasi yang akan mendukung perencanaan strategi sistem informasi. Pola solusi teknologi informasi ini akan dibangun sesuai dengan kebutuhan dari sistem informasi.

Pola Solusi Teknologi Informasi

a. Server Aplikasi, Basis Data, Backup dan Proxy

b. Server

c. Router

d. Jaringan Internet (Access Point)

e. Mobile Device Pendataan

f. Mobile Device Pemetaan

g. Teknologi Unmanned Aerial Vehicle (Pesawat Tanpa Awak)

h. Personal Computer Desktop core i5

i. Access Switch (server dan client)

j. UPS

k. GPS

\section{Manajemen Strategi SI/TI}

Strategi manajemen SI/TI pada Dinas Pendapatan, Pengelolaan Keuangan dan Aset Kabupaten Kampar didapat dari hasil analisis perencanaan strategis sistem informasi dan teknologi informasi berupa kebijakan organisasi dalam menerapkan strategi SI/TI.

Adapun manajemen strategi SI/TI yang direkomendasikan yaitu :
a. Usulan Struktur Organisasi Baru
b. Tugas Pokok Fungsi Setiap Bidang
c. Pengembangan Kompetensi SDM
d. Pengelolaan Pendapatan Asli Daerah

D. Roadmap Pengembangan

Tabel 6. Roadmap Pengembangan

\begin{tabular}{|c|c|c|}
\hline Tahun & Sistem Informasi & $\begin{array}{l}\text { Teknologi } \\
\text { Informasi }\end{array}$ \\
\hline 2016 & $\begin{array}{l}\text { - SIP Hotel } \\
\text { - SIP Restoran } \\
\text { - SIP Hiburan } \\
\text { - SIP Reklame } \\
\text { - } \text { SIP Air Tanah } \\
\text { - } \text { SIP Mineral } \\
\text { Bukan Logam } \\
\text { dan Batuan }\end{array}$ & \begin{tabular}{|l} 
- \\
Server \\
Aplikasi, Basis \\
Data, Backup \\
dan Proxy \\
Server
\end{tabular} \\
\hline 2017 & 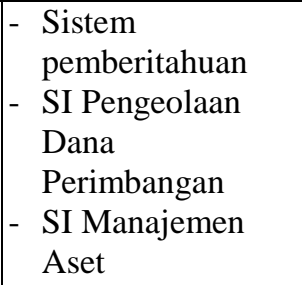 & 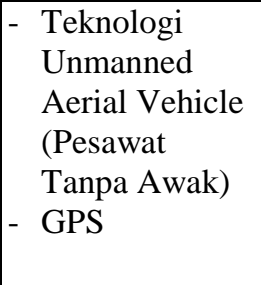 \\
\hline 2018 & 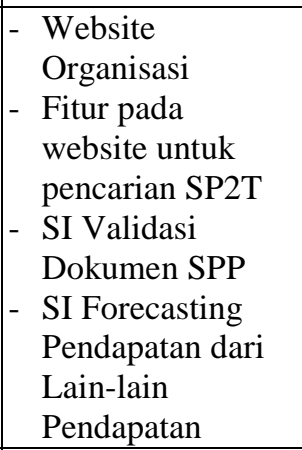 & $\begin{array}{ll}- & \text { Access Switch } \\
\text { (server dan } \\
\text { client) } \\
\text { - Jaringan } \\
\text { Internet } \\
\text { (Access Point) }\end{array}$ \\
\hline 2019 & \begin{tabular}{|l} 
- \\
Aplikasi \\
Pendaftaran \\
Objek Pajak \\
Berbasis Web dan \\
Mobile \\
- Aplikasi \\
Pendaftaran dan \\
Pelaporan Pajak \\
Berbasis Web dan \\
Mobile \\
- SI Geografis \\
Berbasis Web
\end{tabular} & $\begin{array}{ll}\text { - Personal } \\
\text { Computer } \\
\text { Desktop core } \\
\text { i5 } \\
\text { - UPS }\end{array}$ \\
\hline
\end{tabular}




\begin{tabular}{|l|l|l|}
\hline Tahun & Sistem Informasi & $\begin{array}{l}\text { Teknologi } \\
\text { Informasi }\end{array}$ \\
\hline \multirow{7}{*}{2020} & - SI Potensi Pajak & \\
& Daerah & \\
& - SI Kepegawaian & - Router \\
& - SI Kinerja & - Mobile Device \\
& Pegawai & Pendataan \\
& - SI Pemantauan & - Mobile Device \\
& Pembayaran & Pemetaan \\
& Pajak & \\
\hline
\end{tabular}

\section{KESIMPULAN DAN SARAN}

\section{A. Kesimpulan}

Beberapa hal yang dapat disimpulkan berdasarkan penelitian yang telah dilakukan pada bab-bab sebelumnya dan tujuan dari penelitian ini adalah sebagai berikut:

1. Dengan telah melakukan analisa menggunakan metode value chain, SWOT, CSFs dan McFarlan Strategic Grid. Maka didapatkan 20 rekomendasi sistem informasi, 10 rekomendasi teknologi informasi dan 4 manajemen SI/TI untuk masa depan DPPKA Kampar yang bisa digunakan dan telah dikelompokkan pada analisa McFarlan Strategic Grid. Dari analisa McFarlan Strategic Grid didapat gambaran dukungan di tingkat manajerial untuk mengembangkan sistem informasi dan teknologi informasi yang sudah direkomendasikan.

2. Analisa value chain dilakukan untuk dapat menganalisa apa saja permasalahanpermasalahan yang terjadi pada aktivitas yang ada di DPPKA Kampar. Di DPPKA Kampar terdapat beberapa aktivitas yaitu aktivitas utama terdiri dari 7 aktivitas yang memiliki 26 jumlah permasalahan dan aktivitas pendukung yang memiliki 4 jumlah permasalahan. Dari permasalahan tersebut maka didapat faktorfaktor yang membuat permasalahan itu ada dan bisa mendapatkan solusi sistem informasi dan teknologi informasi untuk kemajuan Dinas Pendapatan, Pengelolaan Keuangan dan Aset Kabupaten Kampar di masa yang akan datang.

\section{B. Saran}

Saran untuk pengembangan penelitian selanjutnya adalah antara lain:

1. Melengkapi metode analisa yang belum dilakukan pada penelitian ini.

2. Melakukan perencanaan strategis dengan menggunakan framework perencanaan strategis yang berbeda.

3. Melakukan perbandingan yang lebih detil dan lengkap terhadap perencanaan strategis pada institusi yang sama tetapi beda daerah.

4. Melakukan penyebaran kuisioner untuk mengetahui tingkat pemahaman responden.

\section{REFERENSI}

[1] David, F. R. (2006). Manajemen Strategis. Edisi sepuluh. Jakarta: Penerbit Salemba Empat.

[2] Grant, R. (2002). Contemporary Strategy Analysis: Concept, Techniques, Application (4th ed.). Massachussetts: Blackwell .

[3] Hartono, J. (2006). Sistem Informasi Strategik untuk Keunggulan Kompetitif Edisi 2. Yogyakarta: Penerbit Andi.

[4] Indrajit, R. E. (2001). E-commerce Kiat dan Strategi Bisnis di Dunia Maya. Jakarta: Elex Media Kompetindo Kelompok Gramedia.

[5] Laudon, K. C. (2004). istem Informasi Manajemen (Mana- gement Information Systems, Managing the Digital Firm) T Edisi Kedelapan. Yogyakarta: Penerbit Andi.

[6] O'Berien, J. A. (2003). Introduction to Information System edisi ke-11. New York: McGrawHill/Irwin Companies,inc.

[7] O'Brien, J. A. (2005). Introduction to Information System, 12thed. New York: McGrawHill/Irwin Companies,inc.

[8] Rangkuti, F. (2006). Analisis SWOT, Teknik Membedah Kasus Bisnis. Jakarta: Gramedia Pustaka Utama.

[9] Subardi, A. (2001). Manajemen Pengantar Edisi Revis. Yogakarta: Unit Penerbitan dan Percetakan Akademi Manajemen; Hal.3-4.

[10] Turban, E. e. (2005). Introduction to Information Tecnology. New ork: The Free Press.

[11] Ward, J. P. (2002). Strategic Planning for information sysstem. London: John Wiley \& Sons Ltd. 